\title{
Effect of Mineralogical Properties of Iron Ore on Its Assimilation with Lime
}

\author{
Yukihiro Hida, Jun OKaZaki, Kaoru Iтo and Shunichi Hirakawa
}

\begin{abstract}
Synopsis :
In order to clarify the influences of iron ores on their sintering performance based on their mineralogical properties, assimilation experiments of iron ores and artificial ores prepared from reagents were carried out. The assimilation rate of ore and the microstructure of assimilated portion differed greately among ores. Dense quartz-bearing Ore-A, a representative one of group-(a) classified according to mineralogical properties, was difficult to assimilate and porous pisolite Ore-D containing clay as gangue minerals (group(d)), by contrast, assimilated very rapidly. While the assimilated portion of Ore-A consisted of acicular calcium ferrite that had adhered firmly on the surface of unmelted ore particle, that of Ore- $D$ comprised of very small granular hematite grains, glassy silicate and very large pores and seemed very brittle. Ore-C containing clay (medium group (C) showed the intermediate behavior between those of Ore-A and Ore-D. By the assimilation experiment of artificial ores, an assimilation rate equation expressed as functions of temperature, pore volume of ore and phase composition of gangue minerals was developed. On the basis of such a reiationship between mineralogical prorerties of ore and its assimilation behavior, the deterioration in sintering operation as the various ore brands were interchanged could be clearly explained.

Key words : iron ore; pisolite; ore property ; iron ore sinter; assimilation ; pore structure ; calcium ferrite; melt; ironmaking.
\end{abstract}

\section{1. 緒}

\section{言}

鉄鉣不の銘唡変更によって焼結操業成績は人きく変わ る。新日本製鉄株式会社ではブラジル商鉱石中での多孔 啠高品位鉣不への㧞替"1)，あるいは高ゲーサイトの豪州

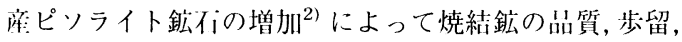
生産性などの业化が顕在化し, 問題となってきた。

㸝知のように，焼結操業成績は鈗石が融夜に同化して いくときの挙動及び司化後の鈗物組織と密接に関連す る. 先に鉄鉣不を融液との成忍前の鉱物学的特性から 4 つのグループに分類したが゙，间化挙動が銘柄でなく， この鉱不の基本的な特性で整理できないかと考えた。

自溶性焼結鉱製造での大部分の初期融液は、酸化鉄と $\mathrm{CaO}$ の店忍によって生成することが明確なので 鈗石粒子に $\mathrm{CaO}$ を接触させた同化実験を行うことにし
た。本報では，鉄鉣石の鉱物特性と $\mathrm{CaO}$ との同化速度 及び闹化後組織の関係について述べる。なおこれらに 関連する研究発表は極めて少ない，焼結鉱製造過程の鉱 不の溶融速度について角戸ら ${ }^{6)}$ 及び佐藤ら゙の報告があ るが, 前者は $\mathrm{Fe}_{2} \mathrm{O}_{3}, \mathrm{CaO}, \mathrm{TiO}_{2}$ および $\mathrm{MgO}$ の緻密 な試薬成型・烧結体の $\mathrm{CaO}-\mathrm{Fe}_{2} \mathrm{O}_{3}$ 系融体への溶解速度 を調べたものであり，鉄鈗不中の主要脈石成分の $\mathrm{Al}_{2} \mathrm{O}_{3}$ 及び $\mathrm{SiO}_{2}$ については検討されていない.また後者では, 溶融速度を “高温粒子気孔率” の 1 次関数で扱ってお り，鉱石中の脈石の影響は考虑されていない。本研究で は，同化に及ほす加熱後気孔割令，脈石の種類と量，龟 裂や粗大気孔を考虑した気孔構造などの影響を父絡しな いように分離して調查し，鈗不の銘柄ではなく基整特性 と同化挙動の関係を明らかにした。

平成 3 年 11 月 8 日受付 半成 4 年 4 月 10 日受理（Received on Nov. 8, 1991; Accepted on Apr. 10, 1992)

* 新H本製鉄(株)プロセス技術研究所 I博 (Process Technology Research Laboratories, Nippon Steel Corp., 20-1

Shintomi Futtsu 299-12)

*2 新甘本製鉄(株)プロセス技術研究所（Process Technology Research Laboratories, Nippon Steel Corp.)

*3 新H本製鉄(株)プロセス技術研究所 (現: 新日鉄製鉄(株)先端技術研究所) (Process Technology Research Laboratories, Now Advanced Materials \& Technology Research Laboratories, Nippon Steel Corp.)

*4 新H本製鉄(株)窒蘭製鉄所（Muroran Works, Nippon Steel Corp.) 


\section{2. 実 験 方 法}

\section{$2 \cdot 1$ 同化実験}

\section{$2 \cdot 1 \cdot 1$ 问化実験 $-(\mathbf{a})$ : 鉱石性状と同化挙動}

(1) 試料

钫物特性にしたがって分類した既報3゙の@（○及び@ の各グループを代表し，かつ使用比率の高いものとして ブラジル彦の緻密質鉣不 $\mathrm{A}$ ，豪州産の粘十系脈石を含む

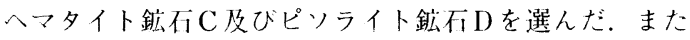
近年鉱不 $\mathrm{A} に$ 代わってブラジルより入荷量が増加してき た高品位鉱不 $\mathrm{B}$ も加えた。これら鉏不の平㚬組成及び水 銀厅人法で測定した加熱後の試料 $1 \mathrm{~g}$ 当りの $100 \mu \mathrm{m}$ 以 下の気孔の量 $(\varepsilon)$ を Table 1 に示す.

\section{( 2 ) 実験方法}

鉣不特性の影響が明確になるように，モデル化擬似粒 子の微小充墳層焼成実験を採用した。まず 3-5 mm の鉱 石䊀子に試薬の $\mathrm{CaO}$ 粉末（10 $\mu \mathrm{m}$ 以下）を付着させた 擬似粒子を調製した。ここで $\mathrm{CaO} /$ 鉱不の質量比は実機 配合原料に近似させるように0.1とした。つぎこ の擬似粒子を $\mathrm{Ni}$ 製るつほ（内径 $10 \mathrm{~mm}$, 高さ $10 \mathrm{~mm}$ ) に允填して電気炉内で $1250^{\circ} \mathrm{C} に 60 \mathrm{~s}$ で昇温し, $120 \mathrm{~s}$ 保持した後，冷水中に入れた。同化状況は，るつほ下面 から $2 \mathrm{~mm}$ の位置を切断, 研磨して調べた。

$2 \cdot 1 \cdot 2$ 闰化実験 $-($ b $):$ 问化速度の測定

実験一（a）の方法では，同化速度を精度よく評価でき なかったので, Fig. 1に示すように, $5 \mathrm{~mm}$ 角に切り出 した鉱不試料を $\mathrm{CaO}$ タブレット上に㯰いて $20^{\circ} \mathrm{C} / \mathrm{s}$ の 速度で加熱し， $1250^{\circ} \mathrm{C}$ あるい $1300^{\circ} \mathrm{C} に 120$ または $240 \mathrm{~s}$ 保捇後, バネの力を利用して水水中に入れてク工 ンチした，鉙不粒子に熱電对を埋め込んで計測した泠却 速度は $1900^{\circ} \mathrm{C} / \mathrm{s}$ であった。

既報 ${ }^{3)}$ の鉱石の分類結果から，同化速度の支配因子と して（1）加熱後気孔割全，(2)脈不の種類と（3)量及 び（4)酸化鉄粒子の大きさの 4 つが考えられた。この ため鉄鉏石のほかにこれら因子の影響を分離して調查で きる模擬鉱石を準備した。模擬鉱石は，粉末のへマタ亿 卜試薬を種々の気孔率在有するタブレット（值径 15

Table 1. Composition of iron ores used and their pore volume after heating.

\begin{tabular}{r|cllll}
\hline Sample & \multicolumn{1}{|c}{$\mathrm{Fe}$} & $\mathrm{SiO}_{2}$ & $\mathrm{Al}_{2} \mathrm{O}_{3}$ & $\mathrm{C}$ W. & \multicolumn{1}{c}{$\varepsilon$} \\
\hline Ore A & $64.3 \%$ & $5.22 \%$ & $1.08 \%$ & $1.14 \%$ & $0.039 \mathrm{~cm}^{3} / \mathrm{g}$ \\
$\mathrm{B}$ & 67.8 & 0.66 & 0.69 & 1.00 & 0.054 \\
$\mathrm{C}$ & 62.5 & 4.66 & 2.66 & 3.04 & 0.054 \\
$\mathrm{D}$ & 57.1 & 5.67 & 2.69 & 8.20 & 0.064 \\
\hline
\end{tabular}

1) C. W. : Combined water

2) $\varepsilon$ : Pore volume after heating up to $1350^{\circ} \mathrm{C}$

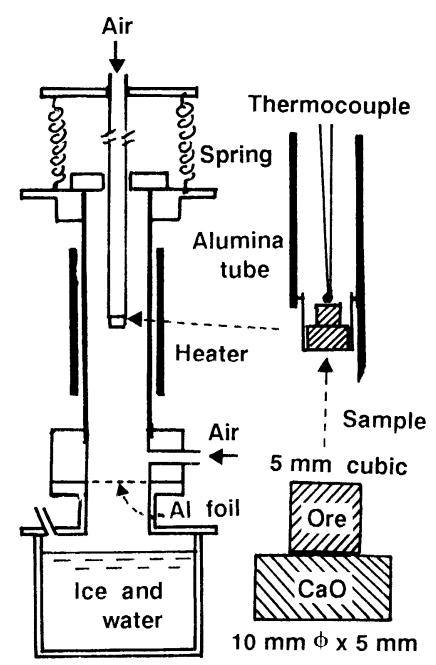

Fig. 1. Scheme of apparatus and sample used in assimilation test-II for measuring assimilation rate.

$\mathrm{mm}$, 高さ $10 \mathrm{~mm})$ に成型し, $1300^{\circ} \mathrm{C} て ゙ ~ 4 \mathrm{~h}$ 焼成して 作成した。な扩，脈石として，代表的粘土鉱物のカオリ ナイト $\left(\mathrm{Al}_{2} \mathrm{O}_{3} \cdot 2 \mathrm{SiO}_{2} \cdot 2 \mathrm{H}_{2} \mathrm{O}\right)$ ，ギブサイト $\left(\mathrm{Al}_{2} \mathrm{O}_{3} \cdot \mathrm{H}_{2} \mathrm{O}\right)$ の仮焼微粉末 $\left(10 \mu \mathrm{m}\right.$ 以下) 及び破砕した珪石 $\left(\mathrm{SiO}_{2}\right)$ 粉を成型前にへマタイト試薬に添加した。间化率は，同 化実験後の試料中央を切断，研磨して未同化鉣不の面積 $\left(S \mathrm{~cm}^{2}\right)$ を測定し，间化实験前の断淔積 $\left(S_{0} \mathrm{~cm}^{2}\right)$ を基 準にして(1)式から求めた。ここで闹化部の判走につい ては試料断面を顕微鏡で観祭し，融液がへマタイト結晶 粒子間に浸入して局粒子が完金に融液に取り讲まれてい る部分は间化しているとした。

同化率: $=1-S / S_{0}$ (1)

\section{$2 \cdot 2$ 粗大気孔の生成原因解明実験}

後述のようにピソライト鉱石では间化時に大きな気孔 を形成し，その原四の…つに結合水の分解によって発生 する亀裂が考えられた。しかし，亀裂を含む $5 \mathrm{~mm}$ 角試 料の作成は難しかったので上記の间化実験-(a)の方法 を採用した。ただ、ヒートパターンは焼結ベッドの場 余に近似させて, $1100^{\circ} \mathrm{C}$ 战最高温度 $\left(T_{\max }\right)$ の $1300^{\circ} \mathrm{C}$ までを $60 \mathrm{~s}$, 降温過程の $T_{\text {max }}$ から $1100^{\circ} \mathrm{C}$ ま でを $180 \mathrm{~s}$ かけた。試料は気孔構造の異なるもので，以 下のようにして調製した。

\section{(1)気孔率の異なる模擬鉱不}

2-5 mm の鉱石 A あいは鉱不 Dを $44 \mu \mathrm{m}$ 以下に粉砕 し，その粉状鉣石を気孔率 30-40\%（水銀厈人法で測定） のタブレット $(15 \mathrm{~mm} \phi \times 10 \mathrm{~mm} H)$ に成型した後, マグ ネタイトが牛成しないように空気を流しながら $1300^{\circ} \mathrm{C}$ 
で 2-3 h 加熱処理した. 徐冷後, 破砕して2-3 mm の粒 度に揃えて試料とした。

( 2 )気孔径の異なる模擬鉱石

$44 \mu \mathrm{m}$ 以下に粉砕した微粉鉱石に0.25-0.5 mm の揮 発物質(ナフタリン)を混入させてタブレットを成型後, 気孔率の異なる模擬鉱石と同様にして試料を作成した。

( 3 ) 亀裂を有する模擬鉣不

上記の気孔率の異なる模擬鈗不と同様にタブレットを 作成して $1300^{\circ} \mathrm{C} て ゙ 2 \mathrm{~h}$ 加熱後, 冷水の中で急冷して亀 裂を発生させ, 2-3 mm の試料に破砕, 調整した。

(4)ピソライト鈗石と類似の亀裂を有する模擬鉱石

2-5 mm の鉱石 A，あるいは鉱石Dを粉砕して 0.25 , $0.5,1.0 \mathrm{~mm}$ で分級後, $0.25-0.5 \mathrm{~mm}$ 粉が $40 \%, 0.5-1$ $\mathrm{mm}$ 粉が $60 \%$ となるように混合してタブレットを成型 し, これを $1300^{\circ} \mathrm{C} に て 2 \mathrm{~h}$ 加熱後, 冷水中に入れて急 冷し，つぎに 2-3 mm に破砕して供試料とした。

\section{3. 実験結果および考察}

\section{$3 \cdot 1$ 鉱石特性と同化挙動}

同化実験- (a) 後の試料断面の鉣物組織を Photo. 1(a)に, 試料表面の走査電顕 (SEM) 像を同写真 (b)に 示す，同化の様子は, 鉱石の鉱物特性によって大きく異 なっている。まず緻密質鉱不A（@）グループ, 脈石 : 石 英) では, 表面部分から徐々に同化しており, 残留元鉱 は大きい. 同化部は針状のカルシウムフェライト (CF) から成り, 緻密で残留元鉱に密着している。一方, ゲー サイトを多量に含み, 最も多孔質の鉱石D（@）グループ, 脈石: 粘土）の場合には, 同化は鉱石 $\mathrm{A} に$ 比べて速く, 残留元鈗は著しく小さくなっている．融液は鉱石中へと 染み込んで拈り，同化部と残留元鉱の境界は明確でない. 残留元鉱には大きな亀裂も認められる。ささらに同化部で は $100 \mu \mathrm{m}$ 以上の粗大気孔が数多く発生し，かつ小粒の ヘマタイト結奛 (Hema.) 粒子が主要鉱物となっている. なお，この Hema. 粒子間はガラス質シリケートであっ た.これらの特徴的な鉱物組織は焼結鈗においても観察 されている2)31. また著者らは Dynamic SEM ${ }^{5)}$ を駆使し て針状 CF の生成機構を解明し上記の鉱石による生成 鉱物の違いは鉱石中の気孔割合と脈石成分に原因がある ことを明らかにしている8).

鉱物特性から@グループと(d)グループの間に分類され る(つグループ3) の鉱不 Cは同化速度及び粗大気孔の生成 からは鉱石 AとDの中間といえ, 粒状の Hema. を主要 酸化鉄結晶粒子として生成する点では鉣石Dに近い。高 品位鉣石 B は鉣石 $\mathrm{C}$ に類似していた。しいて違いを述べ れば，鉱石 Bの方が Hema. 粒子が大きく，その表面に
針状 $\mathrm{CF}$ が認められることである.この $\mathrm{CF}$ 生成量の 違いは脈石量の差に起因し，脈石の少ないほど CF 系 融液が生成し易いと考えられた。また粒状 Hema.の大 きさの順序は元の酸化鉄粒子サイズ ${ }^{3)}$ と対応して抢り, これらの Hema. 粒子は 1 次の結晶が融液中で粒成長し たことを示唆している.

これらの同化挙動を基にして鉱石銘柄変更，とくに鉱 石 $\mathrm{A}$ から $\mathrm{B}$ ，あるいは Cから Dへの振替時の焼結操業蚛 化の原因について考察する，雨場合ともに闹化は促進さ れ (後掲 Fig. 2 参照)，焼結鉱は多孔質化して粗大気孔 も増える，とりわけ後者の場合では著しい．前者の場合 には，鉣石中の Hema. が小さくなり，かつ多孔質へと 変化するために，同化部の主要酸化鉄が針状 CF から 粒状 Hema. 粒子へと変わる.

まず焼結べッドの通気性悪化は，鉱石特性と焼結ベッ ド中で著しく通気抵抗の大きな溶融带の通気性の関係3) から以下のように理解できる，既報 ${ }^{3)}$ の結果では，擬似 粒子中の付着粉が難同化性の鉱石 $\mathrm{A}$ でも核粒子が同化の

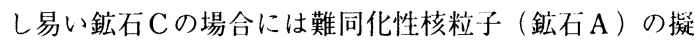
似粒子（付着粉は易同化性の鉱石C）よりも溶融带の通 気抵抗は著しく増加し, 溶融帯は厚くなり, かつ不均に進行した。さらに，溶融带の進行速度も遅延した。溶 融帯の通気抵抗はガスが通過する空隙（溶融前の擬似粒 子間に形成) でほぼ決まると推察されることから，既報 の結果は溶融帯の通気性には極めて短時間に融体化する 付着粉の特性ではなく, 核粒子の同化性が影響すること を示している．すなわち同化が速い鉱石 $\mathrm{A} に$ に切り替える と，核粒子の同化も必然的に促進して融液が急速に増加 し, 上部からの荷重も加わってベッドの空隙を閉塞し, その結果とし溶融带の肥大, 不均一進行化, 進行速度遅 延を引き起こすものと考えられる.

つぎに気孔構造の変化とくに同化部の多孔質化から冷 間強度の低下を説明することができる ${ }^{9)}$. 歩留の低下は, 冷間強度との一般的な正相関関係から類推できるが, Kokubuら ${ }^{10)}$ の鉱石の気孔率と焼結鉱あるいはシンター ケークの空隙率の関係, 及び佐々木ら ${ }^{11)}$ のシンターケー ク空隙率と歩留の関係からも導かれる。とくに鉱石Dで は急速な空隙閉塞が発生するので，それに起因する不均 一な燃焼帯進行と局所的なコークスの未燃焼による熱不 足，いわゆる“焼きむら”も大きく影響する。また，製 銑部会法低温還元粉化性（RDI）の悪化は，鉱物組織及 び $550^{\circ} \mathrm{C}$ 還元率と粉化率の関係 ${ }^{5)} に$ 基づくものといえ る.鉱石 $\mathrm{A}$ から B の場合には, 同化部は針状 CF が減 少して低温で還元し易い Hema. 粒子主体の組織になる こと, 鉱石Cから Dでは粗大気孔と亀裂の生成が引き起 


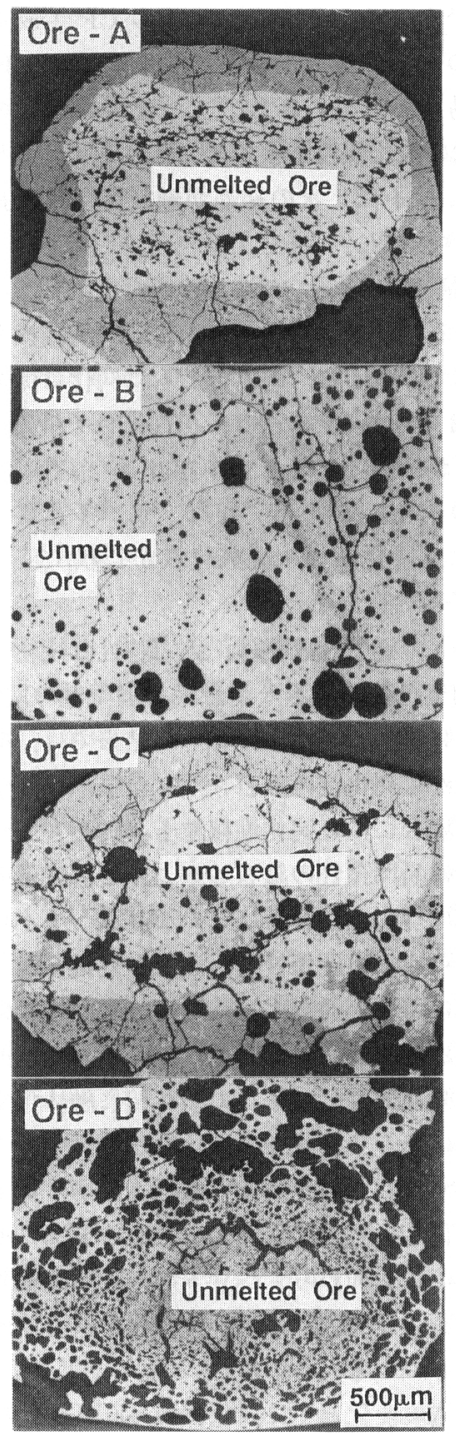

(a) Section

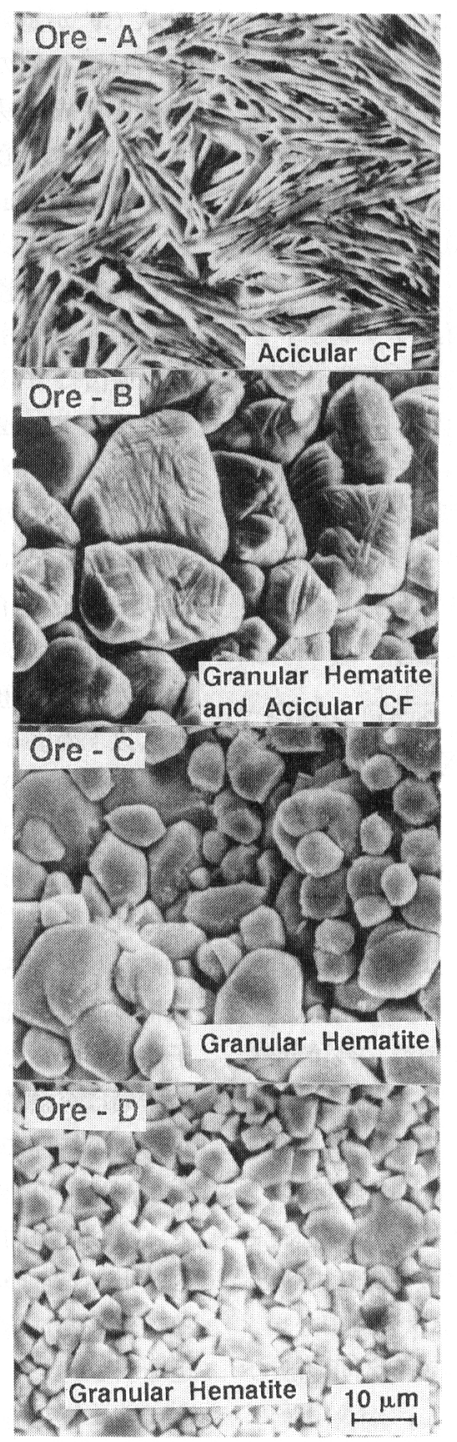

(b) Surface (SEM image)
Photo. 1. Microstructure of cross section of iron ore particles coated with lime and SEM image of their surface after assimilation test $-\mathrm{I}\left(1250^{\circ} \mathrm{C}, 2 \mathrm{~min}\right)$.
こす還元率上昇と結合強度低下によって理解できる. 実験操業解析で, 焼結鉱中 $\mathrm{Al}_{2} \mathrm{O}_{3}$ 分が上昇すると, 必要熱量（コークス原単位）は増え, 歩留, 生産性あ るいは泠間強度が低下するとよく言われる。また配合 原料あるいは同原料中 $-1 \mathrm{~mm}$ 粉の $\mathrm{Al}_{2} \mathrm{O}_{3} / \mathrm{SiO}_{2}$ の増 大によって RDI は悪化する。この $\mathrm{Al}_{2} \mathrm{O}_{3}$ 分あるいは $\mathrm{Al}_{2} \mathrm{O}_{3} / \mathrm{SiO}_{2}$ と娔結操業成績の関係は以下のように前掲 Photo. 1 の鉱石の同化挙動からも説明できる.

鉱石中の $\mathrm{Al}_{2} \mathrm{O}_{3}$ の大部分は粘土鉱物としてゲーサイ トと共存していることから $22, \mathrm{Al}_{2} \mathrm{O}_{3}$ 分の上昇はゲーサ イトの増加を伴う場合が多い。鉱不 $\mathrm{A}$ から鉱石 Cあるい
は鉱石 Dへの振替時にこのような変化が発生する。結合 水分解に要する熱量の増加に加えて, 前掲 Photo. 1 に 示されているように同化速度の上昇および同化部の多孔 質化が起こる。これらの鉱石特性に起因した変化からも $\mathrm{Al}_{2} \mathrm{O}_{3}$ 分上昇時の焼結操業悪化が明確である。また, $\mathrm{Al}_{2} \mathrm{O}_{3} / \mathrm{SiO}_{2}$ の上昇は鉱石 $\mathrm{A}$ から鉱石 $\mathrm{B}$, 鉱石 $\mathrm{C}$ ある は鉱石 Dへの振替に対応する。この場合, 前掲 Photo. 1 から同化部が緻密な $\mathrm{CF}$ 組織から粒状 Hema. 主体の 多孔質組織に，とくに鉱石Dではガラス質シリケートと 粗大気孔が共存したものに変わることは明暸であり,こ の組織の変化からも RDI は悪化すると言える5). 従っ 


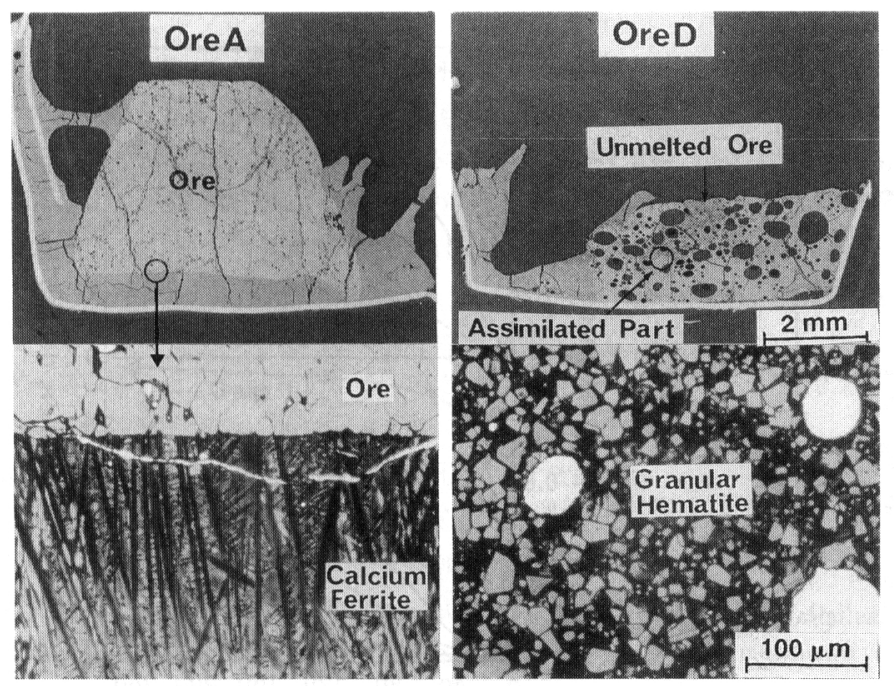

Photo. 2. Macrostructure of cross section of cubic iron ore samples and microstructure of their assimilated portion after assimilation test-II $\left(1250^{\circ} \mathrm{C}, 2 \mathrm{~min}\right)$.

て焼結鉱あるいは原料中の $\mathrm{Al}_{2} \mathrm{O}_{3}$ 含有量は操業管理に 都合のよい指数ではあるが, 焼結操業悪化の本質は $\mathrm{Al}_{2} \mathrm{O}_{3}$ という化合物の直接的な影響よりも鉄鉱石の結合 水，粘土鉱物，気孔率，同化挙動などの特性と関連した ものであることをよく認識しておくことが重要である.

\section{$3 \cdot 2$ 鉄鉱石の同化速度}

性状の大きく異なる鉱石 A とDの同化実験- (b) の結 果の一例 ${ }^{13)}$ をPhoto. 2 に示す.ここでミクロ組織は薄 片試料の透過像である. 先に明らかにした同化挙動の特 徵がそれぞれ明瞭に現れている。両鉱石の同化挙動の違 いは,やや冷めたコーヒー中の砂糖の挙動に例えること ができ, 前者は氷砂糖に近い。後者は角砂糖であり, 小 さな粒子に分断されて元の形状は容易に崩れてしまう. しかし, 酸化鉄粒子が完全に溶解する訳ではない。

Fig. 2 にと $1250^{\circ} \mathrm{C}, 120 \mathrm{~s}$ 後の同化率の関係を示 す。白丸は模擬鉱石の場合の結果である。水銀圧入法で 測定した $\varepsilon の$ 影響は極めて大きい。これは融液が気孔 を通して浸入するためである。試料断面の EPMA 像で は, $\mathrm{Ca}$ は $\mathrm{CaO}$ タブレットと垂直方向に分布しており, この融液浸入現象を裏付けていた.

脈石の影響を Fig. 3 に示す。カオリナイトは同化を 促進するが，石英及びギブサイトは抑制する。このよう に $\mathrm{Al}_{2} \mathrm{O}_{3}$ はその形態によって反対に作用する。石英及 びギブサイトが同化を抑制するのは，試料断面の観察結 果に基づいて作成したFig. 4 の模式図に示すように侵 入融液は急速な融点上昇によって固まり, 緻密層を形成 するためである。石英の場合, Fig. 3 中に併記したご とく粒度によって同化抑制作用に差が認められ，40 $\mathrm{mm}$ 以上では同化率は著しく小さくなった。これは，微細な

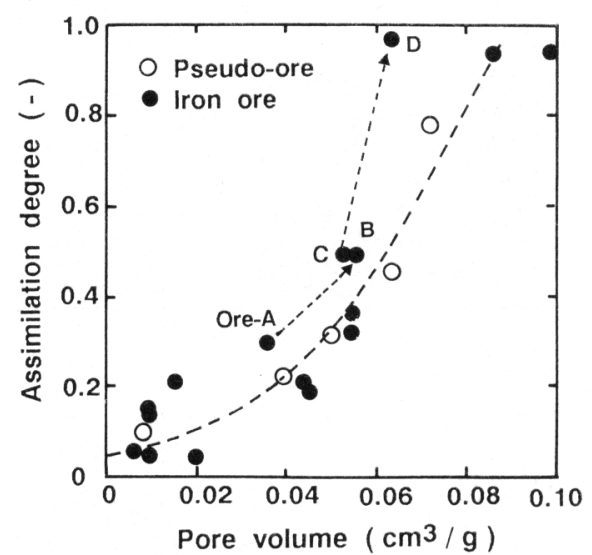

Fig. 2. Relationship between pore volume of artificial ore and iron ore after heating and their assimilation degree at $1250^{\circ} \mathrm{C}$ for $2 \mathrm{~min}$.

石英粒子は融液にす早く溶けてなくなってしまうが，40 $\mu \mathrm{m}$ 以上のものは完全に溶解せず残留するためと考えら れた。また, 試薬焼結体 $\left(1300^{\circ} \mathrm{C}, 72 \mathrm{~h}\right)$ を粉砕して 調査したへマタイト結晶粒子径の影響は, $300 \mu \mathrm{m}$ 以下 の大きさでは極めて小さかった。

鉄鉱石の同化実験結果を前掲 Fig. 2 中に黒丸で示し た。なお，同図中の点 B は後述 Fig. 5 中 Ore-B (a)の 場合の結果である。Ore-B（a）を採用したのは実際の 鉱石と融液の接触状況及び $\varepsilon$ は鉱石全体の開気孔を測 定していることより，Ore-B (a) の方が一般的と考え たからである。同一気孔割合での鉄鉱石と模擬鉱石の同 化率の差は脈石及び水銀圧入法で測定できない $100 \mu \mathrm{m}$ 


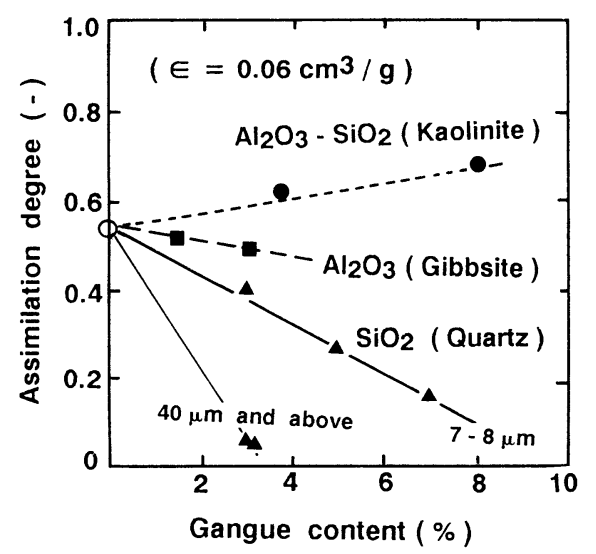

Fig. 3. Effect of gangue minerals on assimilation degree at $1250^{\circ} \mathrm{C}$ for $2 \mathrm{~min}$.

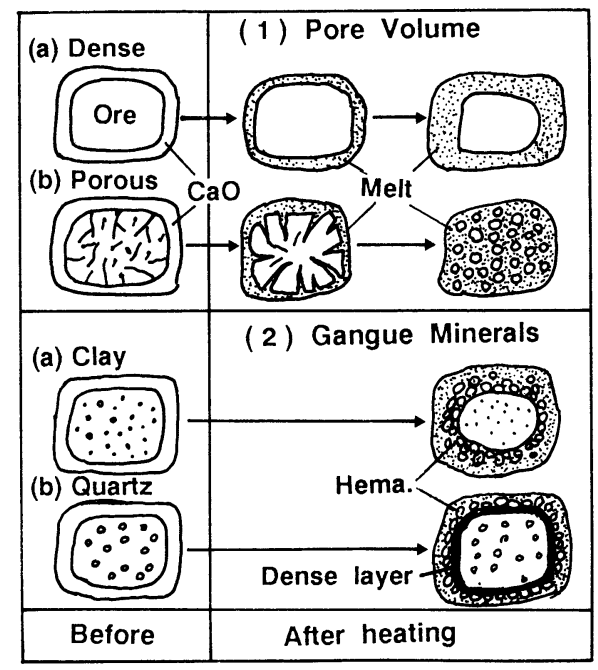

Fig. 4. Schematic diagram of assimilation process of iron ores.

\section{より大きな気孔の影響である。}

Fig. 5 は前記代表鉱石の同化率の時間的変化であり, 脳中の実線は後述の( 3 )式, (4) 式及び( 5 )式を $5 \mathrm{~mm}$ 角の武料に適用して算出した結果である。まず，温度の 上昇によって同化は著しく促進されることが分かる。ま た鉱石特性による差は前掲 Photo. 1 の結果と対忍して いる。鉱石 $\mathrm{A}$ の同化は遅く，鉱石 $\mathrm{D}$ は極めて早い。鉱石 $\mathrm{C}$ はその中間で，鉱石 $\mathrm{B}$ と大きな差はない。鉱石 $\mathrm{B}$ は板 を積み重ねたような層状構造を呈し，板と板の間に空隙 が存在するので, 融液の浸透しやすい面を $\mathrm{CaO}$ と接触 させると同化率は高くなった（Ore-B (a)).

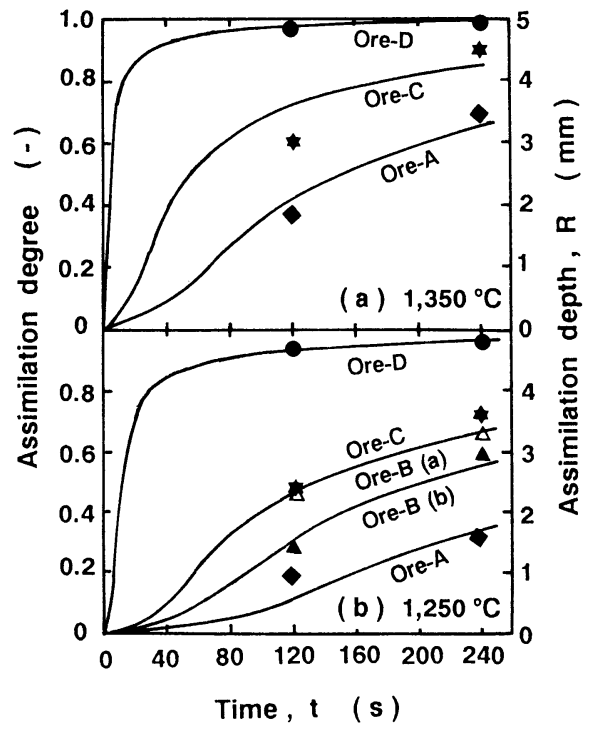

Fig. 5. Assimilation rate of representative iron ores.

以上の同化実験-(b) では融液が立方体試料の一面と 接触するのみであり，粒子全体を融液が取り用む実際の 焼結過程とは異なる。そこで，上記の同化箺験結果を一 般的な粒子の同化にも適用することを検討した。

球形粒子の同化速度は理論的に( 2 )式で表示できる. $d F_{m} / d t=(6 / D) \cdot\left(1-F_{m}\right)^{2 / 3} \cdot(d R / d t) \quad \cdots \cdots(2)$ ここで, $F_{m} / d t$ : 球形鉱石の问化速度 $(-/ \mathrm{s}), F_{m}$ : 球 形鉱石の同化率 $(-), t$ : 時間 $(\mathrm{s}), D, R$ : 鉱石の粒子 径, 同化深さ $(\mathrm{mm}), d R / d t$ : 融液の侵食速度 $(\mathrm{mm} / \mathrm{s})$ で あり， $D$ は初期条件として与えられるため $R$ が判明す れば同化率は求まる。

同化実験-(b) では立方体試料の一面が仅忍面という 特徴のため, $R$ を比較的精度よく測定でき， $R$ と $t$ の 関係は( 3 )式のように近似できた。

$$
R=5 \cdot 10^{-\alpha \cdot \beta / t} \text {. }
$$

ここで， $\alpha$ 及び $\beta$ はそれぞれ温度及び鉣石性状で決まる 関数であり，Fig. 5 に示す結果から $(4)$ 式，また前掲 Fig. 2，3の模擬鉣石の結果から，(5)式を得た。鉱石 中にはカオリン以外の粘土鉱物が存在するが，それらの 影響はカオリンと同一とみなした。また, $\mathrm{SiO}_{2}$ の影響 は粒度が 7-8 $\mu \mathrm{m}$ の場合を用いた。

$$
\begin{aligned}
\alpha & =(14300 / T)-8.40 \cdots \cdots \cdots \cdots \cdots \cdots \cdots \cdots \cdots(4) \\
\beta & =120 \cdot \varepsilon^{2}+5 \cdot(\text { Clay }) \cdot \varepsilon^{2}-24 \cdot(\text { Quartz }) \cdot \varepsilon^{2} \\
& -12 \cdot(\text { Gibbsite }) \cdot \varepsilon^{2}+0.05 \quad \cdots \cdots \cdots \cdots \cdots \cdots \cdots \cdots(5)
\end{aligned}
$$

ここで $T$ : 温度 $(\mathrm{K}),($ Clay), (Quartz), (Gibbsite) : 粘 
土鉱物，石英，ギブサイトの脱結合水後の含有量（\%) である。なお，脈石の同定は，X 線回折，EPMA 解析 などの結果から化学分析值から求めても大きな誤りは生 じないことが判明したので次のように行った。まず $\mathrm{Al}_{2} \mathrm{O}_{3} / \mathrm{SiO}_{2}$ の質量比が 0.45-0.85のものはすべて粘 土鉱物とした。それ以外の場合は, $\mathrm{Al}_{2} \mathrm{O}_{3}$ 分は $\mathrm{Al}_{2} \mathrm{O}_{3} /$ $\mathrm{SiO}_{2}$ が平均値の 0.65 の粘土鉱物として存在するとし, 物質バランスから $\mathrm{SiO}_{2}$ が不足の場合はギブサイトも, また過剩の場合は石英も含まれているとした。

Fig. 6 に，同化実験-(b)の（3)式，(4)式及び( 5 ) 式による計算結果と実験値の対比を示した。比較的よい 一致が認められる。従って, $\mathrm{CaO}$ が $\mathrm{Fe}_{2} \mathrm{O}_{3}$ に対して十 分存在する条件下 (初期融液のモ)カルシウムフェライ 卜組成 ${ }^{8)}$ 以上の $\mathrm{CaO}$ 比率) では( 2 )式，(3)式，(4) 式及び $(5)$ 式から実際の焼結べッドでも同化率を推定で きると考えられる。な㧍，Fig. 6 中で 1 点離れている のは鉱石 Dであり，水銀圧入法で測定できない，100 $\mu \mathrm{m}$ 以上の亀裂及び気孔の補正が今後の課題である.

\section{$3 \cdot 3$ 粗大気孔生成の原因について}

前揭 Photo. 1 及び Photo. 2 のように，とくにピソ ライト鉱石Dでは，同化後，100 $\mu \mathrm{m}$ 以上の大きな気孔 が多数，生成した. Photo. 3 にピソライト鉱石の加熱 後の鉱物組織を示寸。暗灰色の丸い部分（元々へマタイ ト）の周囲の明灰色の領域が加熱前にゲーサイトであっ た所であり，大小の亀裂が多数観察される。また，やや 丸い黒色のものは元々存在していた気孔であり， 200-500 $\mu \mathrm{m}$ 程度の大きなものである。このような構造 から，粗大気孔の生成原因として，鉱石 $\mathrm{A}$ とは異なる鉱 物特性，とくに気孔量，脈石及び鉱石 D中に発生する大 きな亀裂（Photo. 3 参照）などが考えられた。いずれ が支配的因子か検討した結果を以下に述べる.

鉱石 D微粉で作った模擬鉱石の同化状況を Photo. 4 に示す。 $\varepsilon か ゙$ 鉱石 $\mathrm{A}$ の值に近い $0.03 \mathrm{~cm}^{3} / \mathrm{g}$ の場合には, 前揭 Photo. 1 の鉱石 $\mathrm{A}$ の同化状況に類似している（写 真中 (a)).すなわち同化率は $20 \%$ と小さく, 同化部 は $\mathrm{CF}$ 加成り，粗大気孔は発生しない。一方， $\varepsilon$ を鉱 石Dの值以上の $0.13 \mathrm{~cm}^{3} / \mathrm{g}$ としても全体が同化するだ けで, $100 \mu \mathrm{m}$ より小さな気孔しか観察されない（写真 中 (b))。また，同写真（a）と同じように成型，熱処理 したタブレットを水中で急冷して微細な亀裂を多数発生 させた試料の同化実験後においても大きな気孔を生成さ せることが出来なかったささらに，揮発物粒子の添加に よって 100-250 $\mu \mathrm{m}$ の気孔を形成できたが，鉱石D同化 のような粗大気孔は認められなかった。

Photo. 5 は，緻密質鉱石 A を用いて前述の第 $2 \cdot 2$ 節

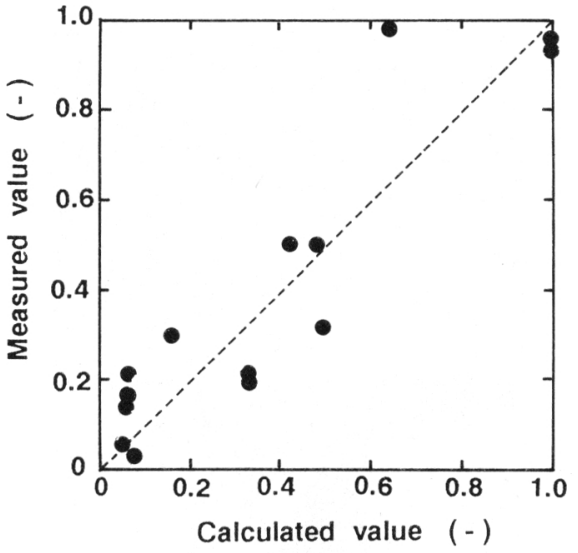

Fig. 6. Comparison of assimilation degree of iron ores at $1250^{\circ} \mathrm{C}$ for 2 min between culculated and measured values.

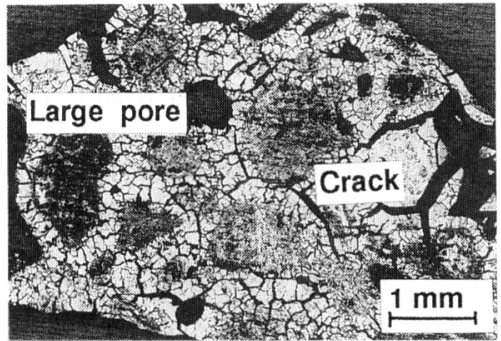

Photo. 3. Large cracks formed in pisolite Ore-D heated rapidly up to $1000^{\circ} \mathrm{C}$.

(4)の方法で作成した模擬鉱石断面とその同化後の様子 を示したものである．模擬鉱石の同化前の気孔構造は同 写真（a）のように前掲 Photo. 3 の加熱後の鉱石 Dに類 似している. Photo. 5-(b) に示すように本模擬鉱石で 初めて粗大気孔が生成した。有姿の試料では緻密な同化

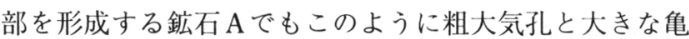
裂を形成させると，同化後には鉱石 $\mathrm{D}$ と同様に粗大気孔 のできることが明らかとなった，本模擬鉱石と鉱石 Dで の特徵的な違いは粒状 Hema. 粒子間の結合相で, 本模 擬鉱石では $\mathrm{CF}$ であった。その理由について鉱石 $\mathrm{D}$ 粉 あるいは鉱石Aとカオリナイトの混合粉から Photo. 5(a) の試料と同料の処理方法で模擬鉱石を作成して検討 し，鉱石 $\mathrm{D}$ と同等のガラス質シリケート結合組織を形成 するには粘土鉱物が必要であることを確認した。

以上の結果から，シリケート結合相形成には粘土鉱物 が必要であるが，鉱石 Dでの粗大気孔生成の主原因はそ の粘土鉱物の脈石ではなく，加熱過程での結合水の分解 による大きな亀裂の発生と元々存在する 200-500 $\mu \mathrm{m}$ の 

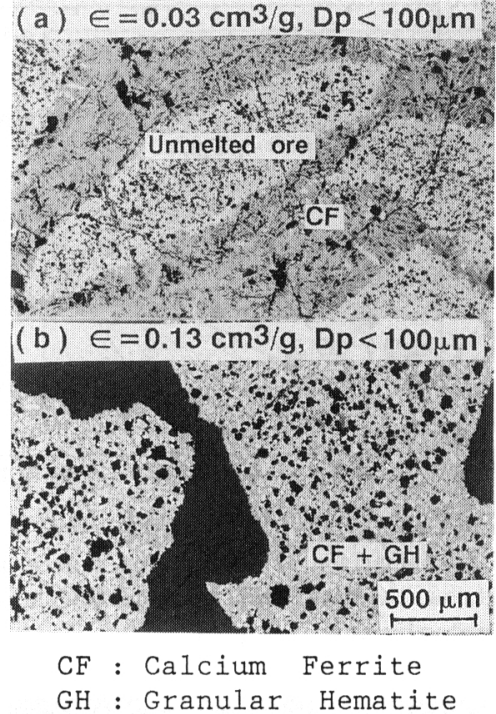

Photo. 4. Microstructure of artifitial ores with different pore volume, prepared from Ore-D powder, after assimilation test $\left(T_{\max }: 1300^{\circ} \mathrm{C}\right)$.

粗大気孔（Photo. 3 参照）にあると結論できた。

\section{4. 結言}

鉄鉱石の鉱物特性と烧結過程での同化挙動の関係を解 明することを目的として，模擬鉱石及び鉄鉱石に $\mathrm{CaO}$ を接触させた同化実験を行い，以下の結果を得た。

(1)脈石が石英で緻密質グループの鉱石の同化は遅 く, 同化部は針状カルシウムフェライト主体の緻密な組 織となり，未同化の鉱石粒子に密着する。

(2) 最多孔質グループに分類される粘土系脈石で高 ゲーサイトのピソライト鉱石の同化は極めて早く, 同化 後は粒状 Hema. 粒子，ガラ又質シリケート及び多数の $100 \mu \mathrm{m}$ 以上の粗大気孔から成る組織が大きな亀裂を有 する小さな残留元鉱を取り囲む脆弱なものとなる。

( 3 ) 上記緻密質グループと最多孔質グループの中間の 鉱物特性を有するグループの粘土系脈石の鉱石は同化挙 動も上記の中間，どちらかといえばピソライト鉱石側に 寄ったものとなる。

(4)鉱石の加熱後気孔量および温度の同化促進作用は 極めて大きい。また脈石の影響は種類によって異なり， 代表的粘土鉱物のカオリナイトは促進し，珪石とギブサ イトは抑制する。

（5）上記因子の影響を定量化して，それらを関数とす る同化速度式を作成した。

（6）ピソライト鉱石同化時における粗大気孔生成の主

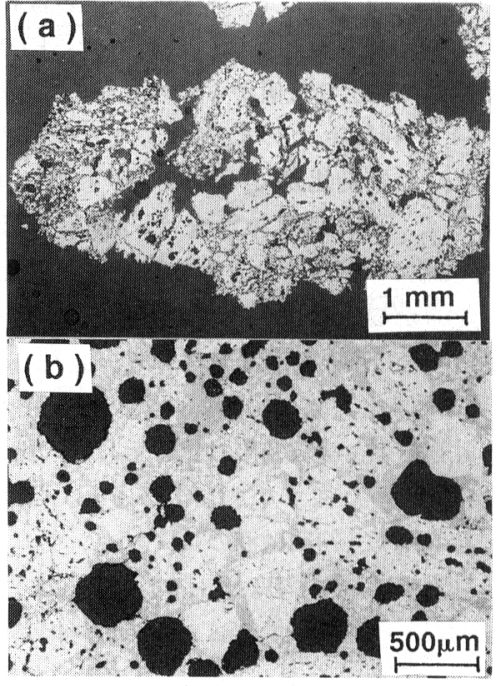

(a) Before assimilation test (b) After assimilation test

Photo. 5. Microstructure of artifitial ore prepared from Ore-A powder before and after assimilatio test.

原因は，高気孔率及び粘土鉱物の含有ではなく，加熱過 程で発生する大きな亀裂である。

\section{文献}

1 ) 岡崎 潤, 肥田行博: 鉄と鋼, 73 (1987), S68

2 ) Y. Hida, J. Okazaki and K. Nakamura : Proc. 6th. IISC, Vol. 2 (1990), p. 48

3 ) 肥田行博, 伊藤 薰, 岡崎 潤, 佐々木棇, 梅津善徳: 鉄と鋼，68（1982），p. 2166

4 ) 佐々木稔, 肥田行博: 鉄と鋼, 68 (1982), p. 563

5 ) 肥田行博, 宮崎武志, 佐々木稔, 相馬英明, 佐藤勝彦, 内藤文雄, 香川正浩, 谷口正彦: 製鉄研究 (1987) 325 , p. 70

6 ）角戸三男，桘谷暢男，岡部俠児：川崎製鉄技報, 9 (1977) p. 6

7 ) 佐藤 駿, 川口尊三，一伊達稔，吉永真弓 : 鉄と鋼，70 (1984), p. 657

8 ) 肥田行博, 岡崎 潤, 伊藤 董, 佐々木稔: 鉄と鋼, 73 (1987), p. 1983

9 ) 佐藤 駿，川口尊三，一伊達稔，吉永真弓 : 鉄と鋼，73 (1987), p. 967

10) H. Kokubu, T. Kodama, H. Itaya and Y. Oguchi : Trans. Iron and Steel Inst. Jpn., 26 (1986), p. 182

11）佐々木三千夫, 小西 勝, 原藤 正, 田口 勇, 稲角忠弘 : 鉄と鋼, 72 (1986)，S 92

12) 肥田行博, 野坂庸二 : 鉄と鋼, 78 (1992), p. 960

13) Y. Ishikawa, Y. Shimomura, M. Sasaki, Y. Hida and H. Toda: Proc. AIME Ironmaking, 42 (1983), p. 17 